\title{
Winter crop sensitivity to inter-annual climate variability in central India
}

\author{
Pinki Mondal • Meha Jain • Andrew W. Robertson • \\ Gillian L. Galford • Christopher Small • Ruth S. DeFries
}

Received: 28 March 2014 / Accepted: 15 July 2014

(C) Springer Science+Business Media Dordrecht 2014

\begin{abstract}
India is predicted to be one of the most vulnerable agricultural regions to future climate changes. Here, we examined the sensitivity of winter cropping systems to inter-annual climate variability in a local market and subsistence-based agricultural system in central India, a data-rich validation site, in order to identify the climate parameters to which winter crops - mainly wheat and pulses in this region - might be sensitive in the future. We used satellite time-series data to quantify inter-annual variability in multiple climate parameters and in winter crop cover, agricultural census data to quantify irrigation, and field observations to identify locations for specific crop types. We developed three mixed-effect models $(250 \mathrm{~m}$ to $1 \mathrm{~km}$ scale) to identify correlations between crop cover (wheat and pulses) and twenty-two climate and environmental parameters for 2001-2013. We find that winter daytime mean temperature (NovemberJanuary) is the most significant factor affecting winter crops, irrespective of crop type, and is negatively associated with winter crop cover. With pronounced winter warming projected in the coming decades, effective adaptation by smallholder farmers in similar landscapes would require additional strategies, such as access to fine-scale temperature forecasts and heat-tolerant winter crop varieties.
\end{abstract}

Electronic supplementary material The online version of this article (doi:10.1007/s10584-014-1216-y) contains supplementary material, which is available to authorized users.

P. Mondal $(\bowtie) \cdot$ M. Jain $\cdot$ R. S. DeFries

Department of Ecology, Evolution and Environmental Biology, Columbia University,

New York, NY 10027, USA

e-mail: pm2658@columbia.edu

A. W. Robertson

International Research Institute for Climate and Society (IRI), Palisades, NY 10964, USA

G. L. Galford

Gund Institute for Ecological Economics, Rubenstein School of Environment and Natural Resources,

University of Vermont, Vermont, VT 05405, USA

C. Small

Lamont-Doherty Earth Observatory, Palisades, NY 10964, USA 


\section{Introduction}

South Asia, particularly India, is predicted to be one of the most vulnerable regions in terms of agricultural sensitivity to future climate changes (Lobell et al. 2008, 2011). Approximately $69 \%$ of India's population is rural, and over $55 \%$ of the working population relies on agriculture for sustenance and livelihoods (Government of India 2013). Food production in India has quadrupled in the monsoon season (kharif crop) and sextupled in the winter season (rabi crop) over the last five decades, even though the total cropped area has remained stable over time (Fig. 1). Agricultural intensification strategies, such as multiple cropping in a unit area over a year, improved seed quality, irrigation, and fertilizer application, attributed to the "Green Revolution", contributed significantly to this increase of agricultural production (Freebairn 1973; Frolking et al. 2006).

Wheat and pulses - two of the most important winter crops in India - together have a 20year annual average (1991-2010) Gross Production Value (GPV) of over 12 billion US dollars, approximately $10 \%$ of India's GPV for food crops (Fig. 2). While cereal production, including rice, wheat, and other grains, in India has seen an overall steady increase over the last 50 years (Fig. 2a), wheat and pulse production has become almost stagnant in the last two decades (Fig. 2b). Previous studies indicate that winter wheat production is already affected by high temperatures (Kalra et al. 2008; Lobell et al. 2011, 2012; Koehler et al. 2013). Even though $91 \%$ of winter wheat is irrigated in India (Singh 2014), smallholder farmers mostly depend on climate-sensitive surface-water irrigation, such as canal irrigation and shallow dug-wells, and do not always have access to high yielding crop varieties. With fewer assets, they are particularly vulnerable to variations in climate (Singh et al. 2002; Morton 2007; Wood et al. 2014).

Yield stagnation for the major food crops in India is likely to continue due to future changes in climate (Mendelsohn 2008; Sanghi and Mendelsohn 2008; Ray et al.

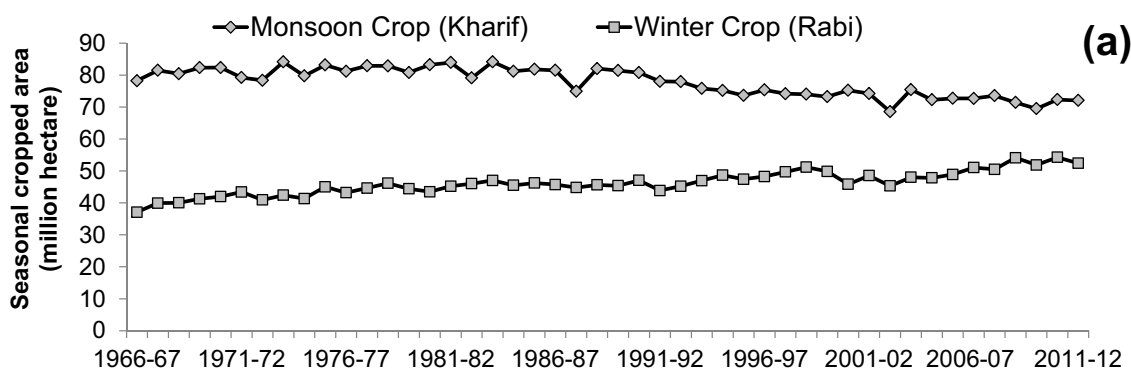

(b)

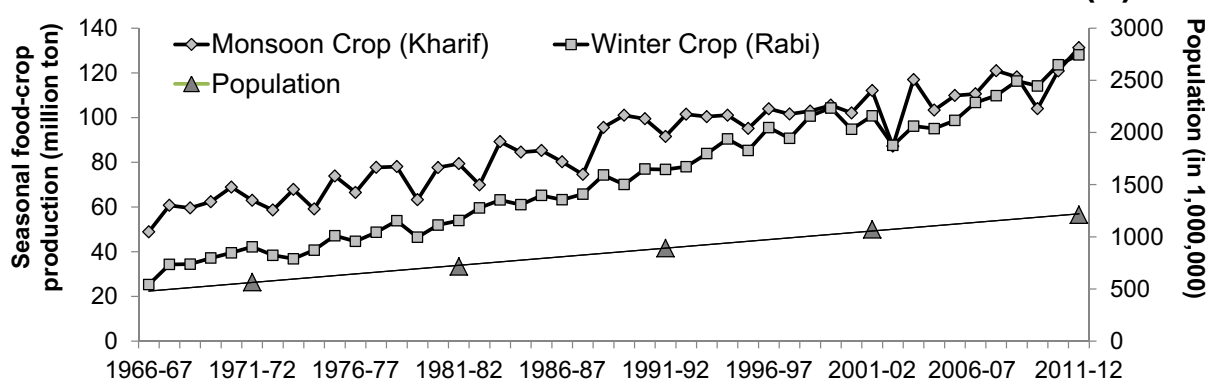

Fig. 1 Seasonal cropped area (a) and food-crop production (b) in India (1966-2012) [Source: Indiastat 2013] 


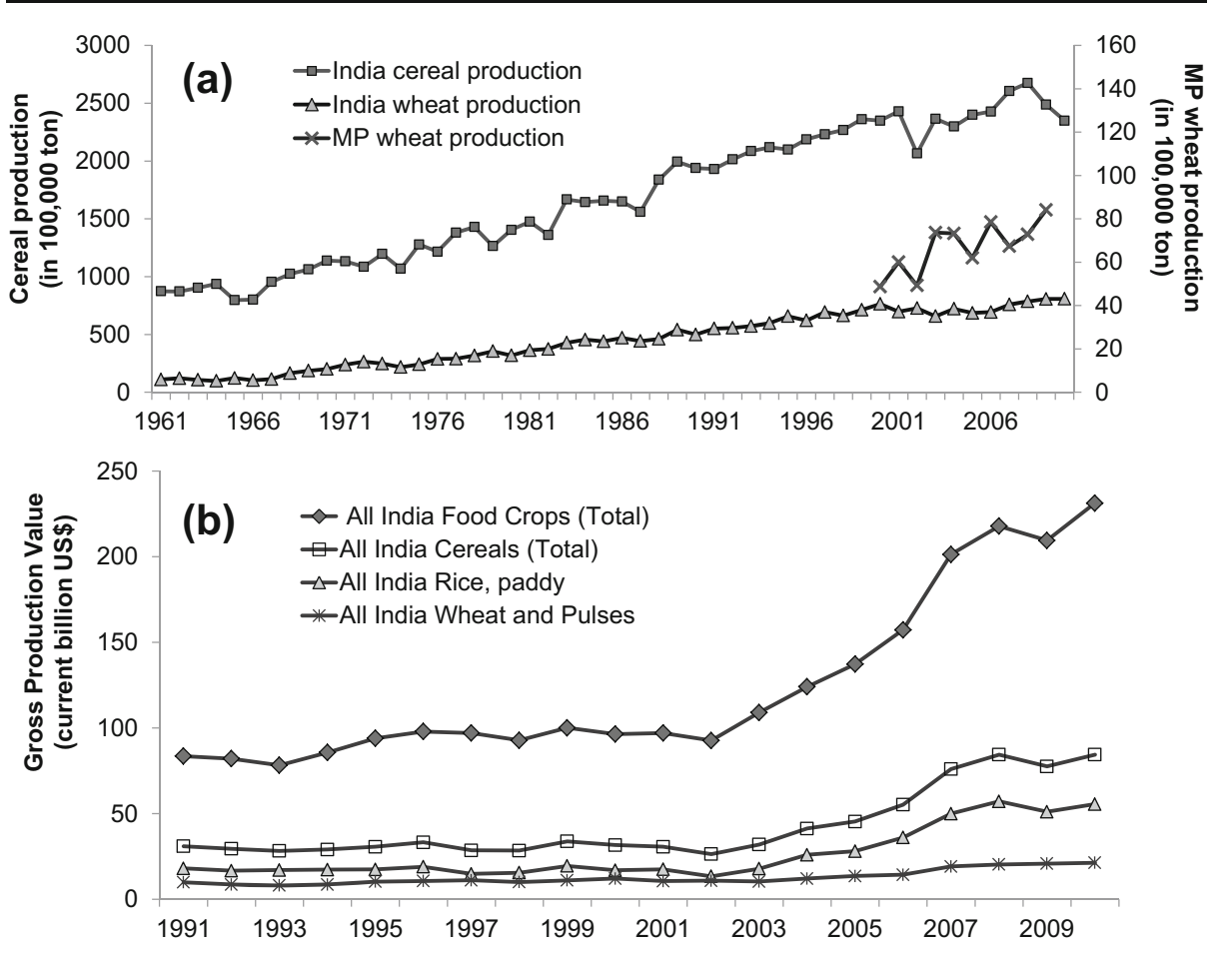

Fig. 2 Cereal production for 1961-2010 in India [Source: FAO, 2013] with wheat production in Madhya Pradesh for the study period [Source: Indiastat 2013] (a) and gross production value for food crops during 19912010 in India [Source: FAO, 2013] (b)

2012; Mueller et al. 2012). Findings from the Coupled Model Inter-comparison Project 5 (CMIP5) indicate that extreme precipitation events $(>40 \mathrm{~mm} /$ day) across all of India are likely to increase in frequency in the second half of this century (Chaturvedi et al. 2012). The PRECIS climate modeling system estimates a $20 \%$ rise in all-India summer monsoon precipitation by 2100 (Kumar et al. 2006). An overall increase in mean surface temperature in the range of $2.5-5{ }^{\circ} \mathrm{C}$ is projected, with more pronounced winter warming (Kumar et al. 2006). Hence, the potential benefits of any increased precipitation on water-limited crops through direct water supply and increased storage of irrigation could be offset by projected increases in temperature (Peng et al. 1995; Wheeler et al. 2000).

Remote sensing is a useful tool in examining smallholder vulnerability to interannual climate variability as it can capture fine-scale changes in crop phenology, otherwise aggregated in village or district-level census data. Crop responses to intraand inter-annual climate variability have been widely assessed using remotely sensed vegetation indices, which can accurately capture cropping patterns, including crop phenology, crop type, and cropping intensity (Xiao and Moody 2004; Sakamoto et al. 2006, 2009; Prasad et al. 2007; Galford et al. 2008; Wardlow and Egbert 2008; Tao et al. 2008; Lobell et al. 2012; Liu et al. 2014). However, satellitederived vegetation indices typically capture biomass status because of their good correspondence with leaf area index. Yield, on the other hand, depends on the transfer of photosynthetic assimilate from leaves to grain. Hence it is possible to have poor yield for a good amount of biomass because of any climatic constraint during the 
grain-filling stage. But, in general, biomass (and thus any satellite-derived vegetation index) and yield are expected to be well correlated.

In this study, we used satellite-derived Enhanced Vegetation Index (EVI), calculated from the Moderate Resolution Imaging Spectroradiometer (MODIS), to capture heterogeneity in crop cover across space and time. In India, smallholder fields are typically $<2$ ha, and one MODIS pixel $(250 \times 250 \mathrm{~m})$ can cover several fields. We use the term 'crop cover' to denote both crop greenness (a measure for crop productivity) and crop extent (or field area), since the EVI value at the MODIS pixel level can be influenced by both.

We examined the sensitivity of winter cropping systems to inter-annual climate variability focusing on a local market and subsistence-based agricultural system in central India. The state of Madhya Pradesh in central India consistently produces roughly $10 \%$ of India's wheat (Fig. 2a), and is representative of complex, diverse, and risk-prone farming systems of developing countries (Chambers et al. 1989). We focus on the southeast portion of the state as this region is one of the poorest in Madhya Pradesh with people predominantly belonging to socially excluded tribal communities (UKAID Department for International Development 2014). This region also provides wide variations in agricultural practices and socio-economic indicators (SI Table 1), allowing us to assess which variables are associated with increased vulnerability to climate. In this study we addressed the following questions:

1. How much did winter crop cover vary on an annual basis from 2001 to 2013 in the study region?

2. Which climatic variables, such as monsoon precipitation, winter precipitation, winter daytime temperature, and winter nighttime temperature, best explain annual variations in winter crop cover?

3. How does the sensitivity of the winter crop cover to climate variability differ based on crop type (wheat and pulses)?

Understanding crop responses to inter-annual climate variability in the recent past will help us understand future responses of different crop types to climate change. Identifying relative importance of different climate parameters will help formulate effective adaptation strategies.

\section{Materials and methods}

\subsection{Study region}

The study site spans 31,257 sq. km over four districts, Balaghat, Dindori, Mandla, and Seoni (Fig. 3a). The site is a "hot moist sub-humid" agro-ecological subregion with shallow to deep loamy to clayey, mixed red and black soil types (agro-eco region: 10; see Gajbhiye and Mandal 2000 for details). Average monsoon rainfall is $1225 \mathrm{~mm}$ and average winter rainfall is $30 \mathrm{~mm}$ (SI Fig. 1). The region produces predominantly food crops (rice during the monsoon season, wheat and pulses including chickpea, pigeon pea/tur, lentil/masoor and moong during the winter season) for local consumption and local markets. There is little to moderate access to surface water irrigation (Fig. 3b) through canals, shallow tanks and wells. Groundwater irrigation is negligible for all districts, even though Seoni witnessed an increase in area irrigated through tube-wells over our study period (Fig. 3b). Seoni also witnessed a rapid increase in winter irrigation in the past decade - $12 \%$ in 2001 to $19 \%$ in 2010 (Indiastat 2013). 
(a)
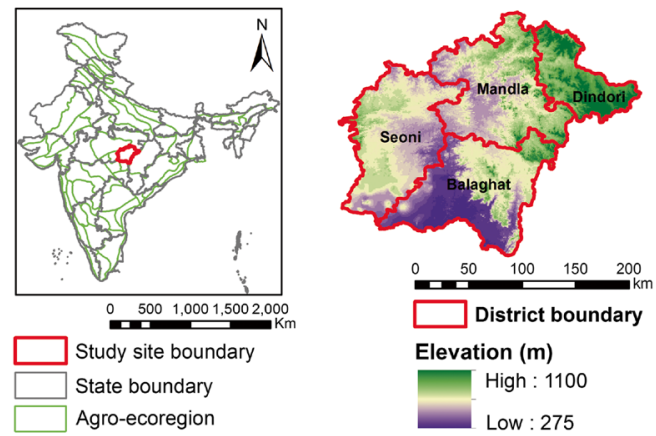

\begin{tabular}{|l|l|l|}
\hline Crop type & Sowing & Harvesting \\
\hline Wheat & $\begin{array}{l}\text { Mid Oct - } \\
\text { End Dec }\end{array}$ & $\begin{array}{l}\text { Mid Feb - } \\
\text { End Apr }\end{array}$ \\
\hline Pulses & $\begin{array}{l}\text { Mid Oct - } \\
\text { End Nov }\end{array}$ & $\begin{array}{l}\text { Mid Feb - } \\
\text { Mid May }\end{array}$ \\
\hline
\end{tabular}

(b)

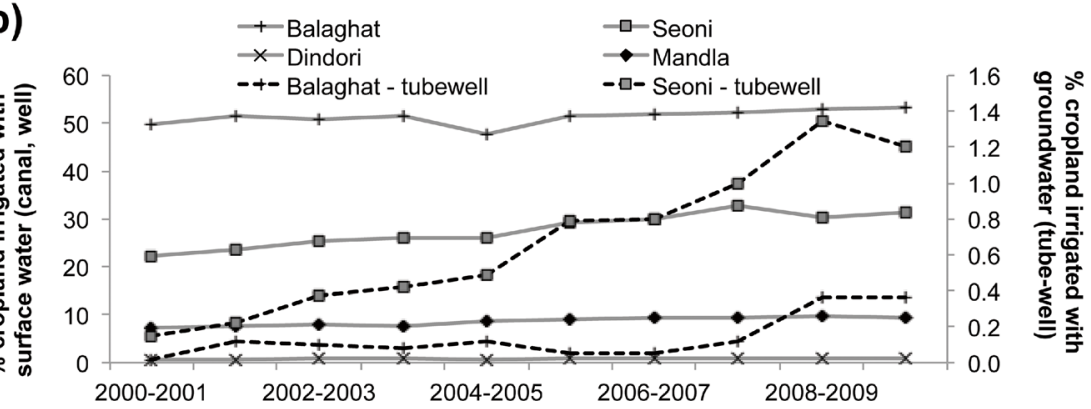

Fig. 3 Characteristics of the study region - location and topography of four districts in the state of Madhya Pradesh in central India and crop calendar [Source: Ministry of Agriculture 2010] (a); proportion of cropland that is irrigated with groundwater and surface water in four districts (b). Digital elevation data (spatial resolution: $1 \mathrm{~km}$ ) was obtained from the Global Land One-km Base Elevation (GLOBE) Project [Source: NOAA, 2013]

\subsection{Response variable}

MODIS EVI data products (May 2000 - March 2013, $250 \mathrm{~m}$ ) were obtained from the IRI/ LDEO Data Library (IRI/LDEO Climate Data 2013). The data are spatial and temporal composites of only the most cloud-free daily values over a 16-day period from MODIS (Huete et al. 2002). EVI was preferred over other remotely-sensed vegetation indices as it better adjusts for background soil and canopy reflectances (Huete et al. 2002). The EVI time-series was smoothed using a cubic smoothing spline function to correct for any remaining highfrequency noise, such as from clouds (see Jain et al. 2013 for details). The smoothed EVI timeseries represents vegetation phenology in the study region, and provides a way to distinguish between single and double crop when all non-crop pixels are excluded. Masks were applied on the time-series to exclude pixels which were never cropped during 2001-2013, and other nonagricultural pixels, including scrubland, forest, bare land and urban areas (see Jain et al. 2013 for details).

The seasonal peak EVI values for each pixel (measured between January 17 and February 1 for each year) were used as the response variable to represent winter crop cover. The peak season span was identified based on our field experience, crop calendar for this region (Fig. 3a; Ministry of Agriculture 2010), and MODIS phenology (SI Fig. 2). As reflected in the crop calendar (Fig. 3a), planting and harvesting time for both wheat and pulses in India can span over several months depending on the crop varieties. Selecting the date for 'peak greenness' can be crucial as different crop varieties can have different spectral 
signatures on a particular date. However, in our study region most cropped fields attain 'peak greenness' (or the booting stage that corresponds to the maximum green biomass development - Benedetti and Rossini 1993) within the time window we selected in this study (SI Fig. 2).

We calculated the coefficient of variation of the peak EVI values at the MODIS scale (Fig. 4a) to examine spatial and temporal variations in winter crop cover during the Jan 17-Feb 1 window. Variations in the peak EVI values were also summarized at the district-level for 2000-01-2012-13 (Fig. 4b). In order to understand crop responses at multiple spatial scales, sensitivity of the peak EVI values to different climate variables were examined at two different scales - one at the MODIS EVI scale for specific crop types $(250 \mathrm{~m})$, and the other aggregated at the MODIS surface temperature scale $(1 \mathrm{~km})$ to match the resolution of the temperature data. We conducted the analyses at two different scales to examine if our findings from the aggregated coarsescale model with a larger sample size are comparable with those from the crop-specific fine-scale models.

\subsection{Predictor variables}

In India where winter wheat/pulses are double cropped with rice, winter crop planting decisions often depend on climatic constraints, management strategies (such as harvesting dates of the previous crop), and farmers' experiences with past weather conditions (Sacks et al. 2010; Waha et al. 2012). In order to evaluate as many driving factors as possible, a total of twenty-two variables were initially examined as predictor variables in the models. Detailed descriptions of these variables are listed in Table 1.

Nine precipitation variables were selected based on existing literature (Mearns et al. 1996; Kumar et al. 2004; Gadgil and Kumar 2006; Chen et al. 2013) and knowledge of the region. While variables such as wet season end date and winter rainy days might have direct implications for winter crop peak EVI, other variables such as wet season start date, total monsoon rainfall, monsoon dry days, and wet season length can affect the amount of soil moisture available for winter crops, and the volume of water available for surface irrigation (Gadgil and Kumar 2006). The precipitation variables were calculated from the Tropical Rainfall Measuring Mission (TRMM) satellite data
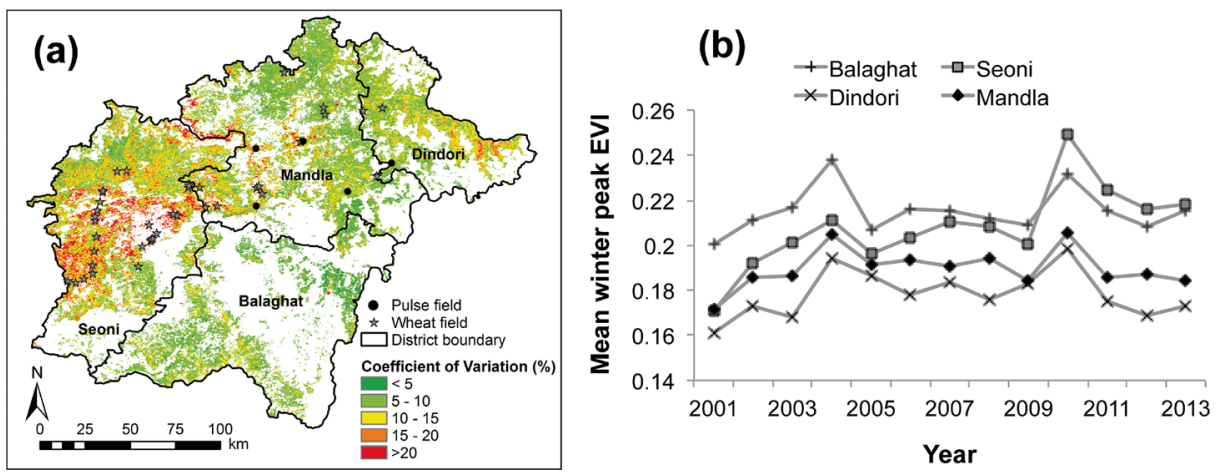

Fig. 4 Spatial and temporal variations in winter crop phenology - spatial distribution of coefficient of variation calculated at MODIS EVI pixel level $(250 \mathrm{~m})$, along with location of 45 ground-truth points collected during winter 2013 (a); inter-annual variability of aggregated crop cover at district-level for 2001-2013 (b) 
Table 1 Response variables used in this study along with their characteristics

\begin{tabular}{|c|c|c|}
\hline Variables & Description & $\begin{array}{l}\text { Source (spatial } \\
\text { resolution) }\end{array}$ \\
\hline Wet season start date (wetstart) & $\begin{array}{l}\text { First wet day }(>1 \mathrm{~mm} \text { ) of first } 5 \text {-day wet spell } \\
\text { (wet spell amount } \geq 13 \text {-years wet season mean } * 5 \text { ) } \\
\text { which is NOT immediately followed by } 10 \text {-day dry } \\
\text { spell with }<10 \mathrm{~mm} \text { (to exclude false start) }\end{array}$ & $\operatorname{TRMM}\left(0.25^{\circ}\right)$ \\
\hline Wet season end date (wetend) & $\begin{array}{l}\text { Last wet day }(>1 \mathrm{~mm} \text { ) of last } 5 \text {-day wet spell which } \\
\text { is NOT immediately preceded by } 10 \text {-day dry spell } \\
\text { with }<10 \mathrm{~mm} \text { (to exclude post-monsoon short spell) }\end{array}$ & $\operatorname{TRMM}\left(0.25^{\circ}\right)$ \\
\hline Wet season length (wetlen) & Wet season end date - Wet season start date & $\operatorname{TRMM}\left(0.25^{\circ}\right)$ \\
\hline Monsoon rainy days (monrainy) & Number of monsoon days with $\mu_{\text {daily }} \geq \mu_{13 \text {-year wet season }}$ & $\operatorname{TRMM}\left(0.25^{\circ}\right)$ \\
\hline Monsoon dry days (mondry) & Number of monsoon days with $\mu_{\text {daily }}<\mu_{13 \text {-year wet season }}$ & $\operatorname{TRMM}\left(0.25^{\circ}\right)$ \\
\hline Winter rainy days (winrainy) & Number of winter days with $\mu_{\text {daily }} \geq \mu_{13 \text {-year dry season }}$ & $\operatorname{TRMM}\left(0.25^{\circ}\right)$ \\
\hline $\begin{array}{l}\text { Monsoon total rainfall } \\
\quad(\text { totalmonrain })\end{array}$ & $\begin{array}{l}\sum \text { rainfall }_{\text {daily }} \text { (for wet season start date to wet season } \\
\text { end date) in } \mathrm{mm}\end{array}$ & $\operatorname{TRMM}\left(0.25^{\circ}\right)$ \\
\hline $\begin{array}{l}\text { Simple Daily Intensity } \\
\text { Index }(S D I I)\end{array}$ & Total monsoon rainfall/number of monsoon rainy days & $\operatorname{TRMM}\left(0.25^{\circ}\right)$ \\
\hline $\begin{array}{l}\text { Monsoon days with no } \\
\text { rainfall (monnorain) }\end{array}$ & Number of monsoon days with $\mu_{\text {daily }}=0$ & $\operatorname{TRMM}\left(0.25^{\circ}\right)$ \\
\hline $\begin{array}{l}\text { Daytime maximum } \\
\text { temperature (win Tmax) }\end{array}$ & $\left.\sum \mu_{\text {monthly }}\right) / 3$ (for NDJ) $\mathrm{T}_{\max }$ in ${ }^{\circ} \mathrm{C}$ & MODIS (1 km) \\
\hline $\begin{array}{l}\text { Daytime minimum } \\
\text { temperature (winTmin) }\end{array}$ & $\left.\sum \mu_{\text {monthly }}\right) / 3$ (for NDJ) $\mathrm{T}_{\min }$ in ${ }^{\circ} \mathrm{C}$ & MODIS (1 km) \\
\hline $\begin{array}{l}\text { Daytime mean } \\
\text { temperature (winTmean) }\end{array}$ & $\left.\sum \mu_{\text {monthly }}\right) / 3$ (for NDJ) $\mathrm{T}_{\text {mean }}$ in ${ }^{\circ} \mathrm{C}$ & MODIS (1 km) \\
\hline $\begin{array}{l}\text { Daytime temperature } \\
\text { range (winTrange) }\end{array}$ & Winter day $\mathrm{T}_{\max }-$ Winter day $\mathrm{T}_{\min }$ in ${ }^{\circ} \mathrm{C}$ & MODIS (1 km) \\
\hline $\begin{array}{l}\text { Nighttime maximum } \\
\text { temperature (winNTmax) }\end{array}$ & $\left.\sum \mu_{\text {monthly }}\right) / 3$ (for NDJ) $\mathrm{T}_{\max }$ in ${ }^{\circ} \mathrm{C}$ & MODIS (1 km) \\
\hline $\begin{array}{l}\text { Nighttime minimum } \\
\text { temperature (winNTmin) }\end{array}$ & $\left.\sum \mu_{\text {monthly }}\right) / 3$ (for NDJ) $\mathrm{T}_{\min }$ in ${ }^{\circ} \mathrm{C}$ & MODIS (1 km) \\
\hline $\begin{array}{l}\text { Nighttime mean temperature } \\
\quad(\text { winNTmean })\end{array}$ & $\left.\sum \mu_{\text {monthly }}\right) / 3$ (for NDJ) $\mathrm{T}_{\text {mean }}$ in ${ }^{\circ} \mathrm{C}$ & MODIS (1 km) \\
\hline $\begin{array}{l}\text { Nighttime temperature } \\
\text { range (winNTrange) }\end{array}$ & Winter night $\mathrm{T}_{\max }-$ Winter night $\mathrm{T}_{\min }$ in ${ }^{\circ} \mathrm{C}$ & MODIS (1 km) \\
\hline Elevation & Elevation in meter & MODIS (1 km) \\
\hline Slope & Slope in degrees & MODIS (1 km) \\
\hline Soil & $\begin{array}{l}\text { Vc: } 22.4 \% \text { sand, } 24.5 \% \text { silt, } 53 \% \text { clay; I: } 58.9 \% \\
\text { sand, } 16.2 \% \text { silt, } 24.9 \% \text { clay; Lc } 64.3 \% \text { sand, } \\
12.2 \% \text { silt, } 23.5 \% \text { clay }\end{array}$ & $\mathrm{FAO}\left(0.083^{\circ}\right)$ \\
\hline Winter irrigation (irri_per) & (Irrigated winter crop area/Net cropped area)*100 & $\begin{array}{l}\text { Agricultural census } \\
\text { (district) }\end{array}$ \\
\hline Access to irrigation & 1 for yes, 0 for no & Field data \\
\hline
\end{tabular}

*NDJ=November-December-January

$\left(0.25 \times 0.25^{\circ}\right)$ for $2000-01$ to $2012-13$, which shows good agreement to station data in this region (SI Fig. 3).

Eight temperature variables were calculated from MODIS land surface temperature (LST) dataset (MOD11A2) from the NASA LPDAAC (USGS 2013). This dataset is an 8-day 
composite of average values of clear-sky LST with a sinusoidal projection and a spatial resolution of $1 \mathrm{~km}$. The data were rescaled to convert to units of degree Celsius and reprojected to the WGS-84 coordinate system. Both the daytime and nighttime LST values from the re-projected and rescaled datasets were used to calculate the temperature variables (Table 1). It is important to note that the precipitation $\left(0.25^{\circ}\right)$ and temperature $(1 \mathrm{~km})$ dataset used in this study are of different spatial resolution. Future studies need to compare the effects of these climatic variables at the same resolution, when available.

Five other relevant variables, soil type, elevation, slope, access to irrigation at the pixel level, and winter irrigation percentage at the district level were also examined (Table 1). Ground-truth points were collected during a field-trip in January 2013 using handheld GPS unit with additional information regarding dominant winter crop types, access to irrigation, and type of irrigation. District-level winter irrigation percentage data were obtained from agricultural census (Indiastat 2013). Since agricultural census data were available only for 2001-2010, winter irrigation percentage data for 2011-2013 were extrapolated using regression models.

\subsection{Mixed-effect models}

We constructed 3 mixed-effect regression models at two different spatial scales - one model at $1 \mathrm{~km}$ for all winter crops to match the spatial resolution of the temperature data, and two models at $250 \mathrm{~m}$ for irrigated wheat, and un-irrigated pulses to match the resolution of EVI data (see SI Table 2 for model details). The coarser scale model ( $n=294,096$ for the entire timeseries over the full study region excluding missing values) does not distinguish between different winter crop types, and includes response variables aggregated to $1 \mathrm{~km}$ and climate variables at their corresponding spatial resolutions. The suite of predictor variables in this model also includes percent of winter irrigation, which was calculated as the proportion of winter irrigated area and the net cropped area for each of the four districts using irrigation census data (Indiastat 2013).

We used 45 ground-truth points (Fig. 4a) collected during January 2013 to construct the two finer scale mixed-effect regression models for wheat and pulses. For each location, data on crop type and presence/absence of irrigation were collected in the field, since agricultural census data are not available at such a fine scale. The ground-truth points were used only if they were collected at locations where crop cover was homogenous at the MODIS scale $(250 \mathrm{~m} \times 250 \mathrm{~m})$ (Fig. 4a). These 45 points were used to extract values for response and predictor variables for the entire time-series (winter 2001-2013) in ArcGIS, resulting in a sample size of 566 (excluding missing values). Sample sizes for the wheat model, and pulse model are 502 pixels and 64 pixels respectively. For the ground-truth points collected, wheat fields were always irrigated (i.e. rainfed with supplemental irrigation), while pulse fields were un-irrigated; hence the binary irrigation variable was not included in individual models for the two crop types.

The "district" variable was used as a random-effect in the regression models to account for different socio-economic (such as market, price, subsidies) and irrigation characteristics. Our study design involved repeated measures of a single pixel for 13 years. To account for this, the random effects in the models also specified the nested effect of the "ID" (unique pixel identification number) random effect within the "district" random effect, thus accounting for any variability that could be contributed by district-specific irrigation type, crop type, market influence, or change planting strategies.

The continuous environmental variables were standardized using the following formula: $\mathrm{x}_{\mathrm{z}}=\left(\mathrm{x}_{\mathrm{i}}-\mu\right) / \sigma$, where $\mathrm{x}_{\mathrm{z}}$ is the standardized value of a particular pixel, $\mathrm{x}_{\mathrm{i}}$ is the original value of that pixel, $\mu$ is the 13-year mean, and $\sigma$ is the standard deviation. Some of the climate variables showed a high degree of multi-collinearity, and were not considered in the regression models. 
Pearson's $r$ was used as a measure for correlation, and collinear variables were eliminated if $r$ was higher than 0.6. Correlation coefficients of the final set of predictor variables are listed in SI Table 3. The Akaike Information Criterion (AIC) (Akaike 1974), which is a measure of the relative quality of each statistical model considering both goodness of fit and the number of parameters in the model, was used to select the final 3 models from a total of 40 candidate models (SI Table 2). SI Fig. 4 shows relative importance of predictor variables based on difference in AIC values calculated from the finer-scale mixed-effect models for wheat and pulses. All analyses were conducted in R Project Software Version 3.0.2, using the raster, rgdal, and lme4 packages (R Development Core Team 2013).

\section{Results}

\subsection{Spatio-temporal variability in winter crop cover}

Winter crop cover in the study region is highly variable, both spatially and temporally (Fig. 4). Seoni witnessed the highest inter-annual variability with a coefficient of variation over $20 \%$ (Fig. 4a). Most parts of Mandla and Dindori show temporal variations less than $10 \%$ (Fig. 4a), except south-western Mandla and eastern Dindori. Balaghat is mostly covered in forests, and show low temporal variability in winter crop cover (Fig. 4b). All four districts had the lowest winter crop cover in the year of 2001, reflected in mean peak EVI values (Fig. 4b); while 2010 was the most productive year (Fig. 4b).

We found a considerable amount of random effects in the regression models. The 'district' variable alone accounted for $13 \%$ of the total random effect variance for wheat model. The location of specific pixels within a district explained $50 \%$ and $55 \%$ of the total variance of random effects in wheat and pulse models respectively. To further decouple spatial and temporal variability, we calculated Pearson's $r$ between seasonal mean temperature and corresponding peak EVI for 13 years for each of the 45 wheat and pulse field locations (see Section 3.3).

3.2 Relative importance of climatic variables in explaining crop variability at multiple scales

\subsubsection{All winter crops - coarse scale model}

The coarse-scale statistical model, involving winter EVI aggregated at $1 \mathrm{~km}$ reveals that the two most important variables to explain winter crop sensitivity are winter daytime mean temperature (for November-January) and winter irrigation, with different directions and magnitude. While one unit increase in winter daytime mean temperature corresponds to a decrease of 0.021 in winter peak EVI, one unit increase in winter irrigation percent can result in an increase of 0.013 in winter peak EVI (Fig. 5a). Winter crop cover is also positively influenced by a greater nighttime mean temperature and daytime temperature range, and late wet season start and end date (Fig. 5a).

\subsubsection{Irrigated wheat - fine scale model}

Standardized coefficients from the regression model for wheat with the lowest AIC value indicate that winter daytime mean temperature is the most overwhelmingly important variable (Fig. 5b, SI Fig. 4), consistent with results from the coarse-scale model. One unit increase in winter daytime mean temperature corresponds to a 0.06 decrease in wheat EVI. An increase in 


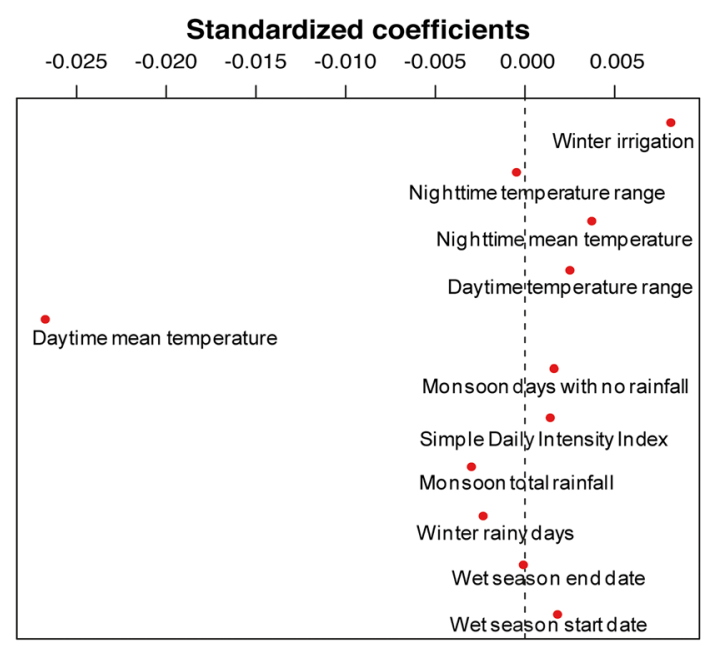

(a) All crop types

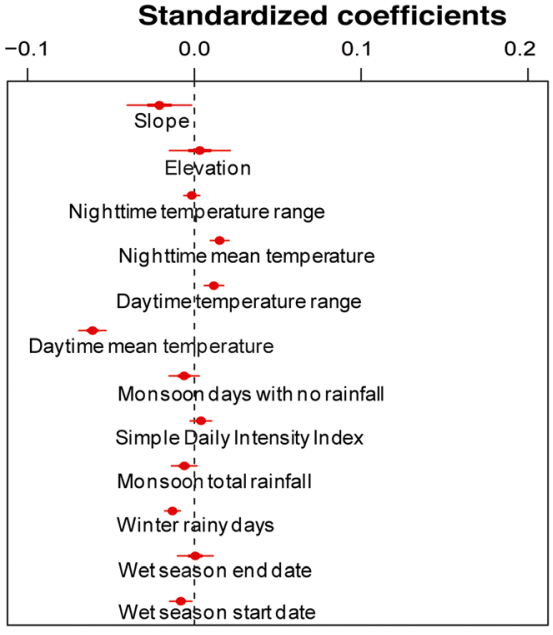

(b) Wheat
Standardized coefficients

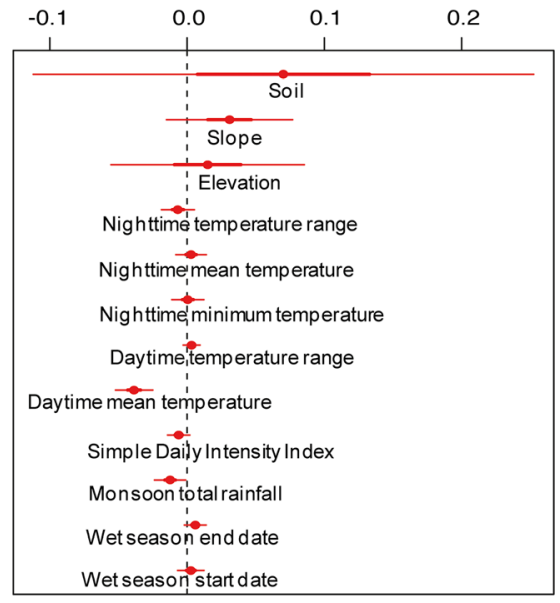

(c) Pulses

Fig. 5 Standardized regression coefficients generated by mixed-effect models ( $95 \%$ confidence intervals) for all winter crops (a), wheat (b), and pulses (c)

winter nighttime mean temperature, however, has a positive effect on winter wheat at a rate of one unit to 0.015 of wheat EVI. Since the locations of ground-truth points collected for wheat were always irrigated, it was not possible to determine the relative importance of irrigation in wheat productivity. It is evident though that access to irrigation plays a pivotal role in decisions of which winter crop to plant. Elevation, slope, and soil influence the type of crop planted, explaining the spatial variations in crop cover (Fig. 5b, c).

\subsubsection{Un-irrigated pulses - fine scale model}

The regression model for pulses with the lowest AIC value identifies the strong negative impacts of winter daytime mean temperature and total monsoon rainfall along with weak 
positive impacts of late wet season start date and end date (Fig. 5c). The negative influence of winter daytime mean temperature on pulse productivity is less than that on wheat productivity (SI Fig. 4). One unit increase in winter daytime mean temperature corresponds to a 0.045 decrease in pulse EVI. One unit increase in wet season end date, meaning a late withdrawal, corresponds to an increase of 0.025 in pulse EVI. An increase in total monsoon rainfall has a negative effect at a rate of one unit to 0.025 of pulse EVI.

\subsection{Decoupling spatial variability and temporal variability - fine scale models}

In order to examine whether differences in crop sensitivity to mean temperature are due to temporal variations, we regressed EVI data on the corresponding local mean temperatures for 13 years at each location and calculated correlation coefficients (SI Fig. 5). As indicated in the figure, more than $73 \%$ of the pixels have strong correlation (Pearson's $r>0.6$ ) between peak EVI and seasonal mean temperature. We further examined effects of daytime temperature throughout the crop growth period until the booting stage. We calculated correlation coefficients between EVI and daytime temperature for every 16-day (temporal resolution of the EVI dataset) for each of the 33 locations where end-January peak EVI is highly correlated $(r>0.6)$ to winter daytime mean temperature (SI Table 4). As indicated in the table, approximately $73 \%$ of the pixels used in this analysis show a stronger negative correlation between EVI and daytime temperature during the booting stage (just before reaching the biomass peak in endJanuary) compared to the initial weeks after sowing.

\section{Discussion and conclusion}

Historical records (1901-2003) indicate a statistically significant positive trend in annual and winter mean temperature in central India (Pal and Al-Tabbaa 2010). These warming trends are projected to continue in the coming decades, especially during the winter season (Kumar et al. 2006). The all India warming trend differs from the study area (Fig. 6), as the national-level studies aggregate the regional-level variations. However, these projections have important implications for winter crop productivity in our study region, as we found winter temperature parameters to play a pivotal role in influencing winter crop cover. All three of our regression models emphasized the strong winter crop sensitivity to winter daytime mean temperature (Fig. 5), and the spatial distribution of inter-annual winter crop variability (Fig. 4a) also broadly corresponds to that of winter mean daytime temperature (SI Fig. 6). Winter nighttime mean temperature has a positive effect on winter crop, especially wheat (Fig. 5b). However, the negative impact of daytime mean temperature is far more overwhelming. The district of Seoni witnessed high variability both in winter crop cover (Fig. 4a) and winter mean daytime temperature (SI Fig. 6). Unlike the other three districts, Seoni also witnessed an overall positive trend in winter crop cover (Fig. 4b) and groundwater irrigation (Fig. 3b) over the last decade. Even if expanding the irrigation network might have led to more winter cropped area (by encouraging more farmers to plant during the winter), our results show that irrigated crops are still negatively impacted by warming temperatures.

Trends in total monsoon precipitation in central India were found to have a statistically significant negative trend during 1954-2003 (Pal and Al-Tabbaa 2011). However, climate models predict an increase in total monsoon precipitation in our study region by 2100 (Kumar et al. 2006). This projected increase in monsoon precipitation, while influencing monsoon crops, will likely have no important implications for winter crops in the central Indian landscape, since most of the precipitation parameters considered in our models have non-significant influences on 
Monsoon total precipitation across years

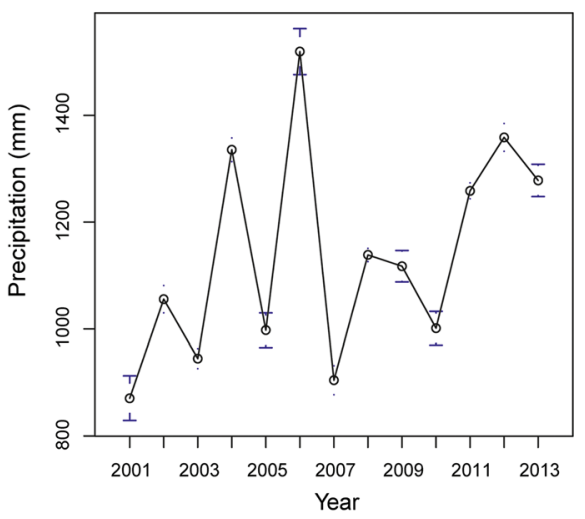

Winter daytime mean temperature across years

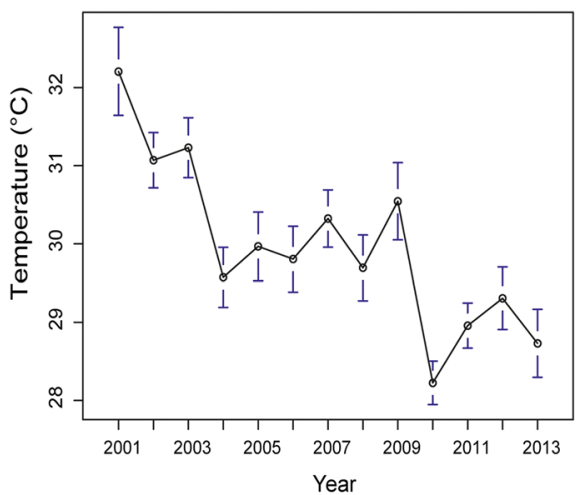

Winter peak EVI across years

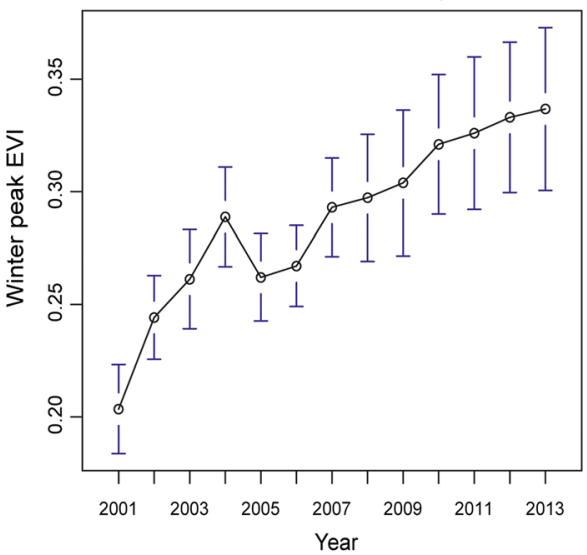

(a) Wheat

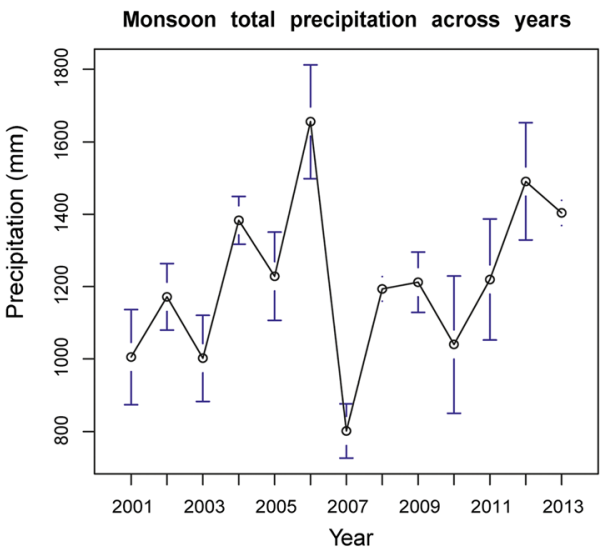

Winter daytime mean temperature across years

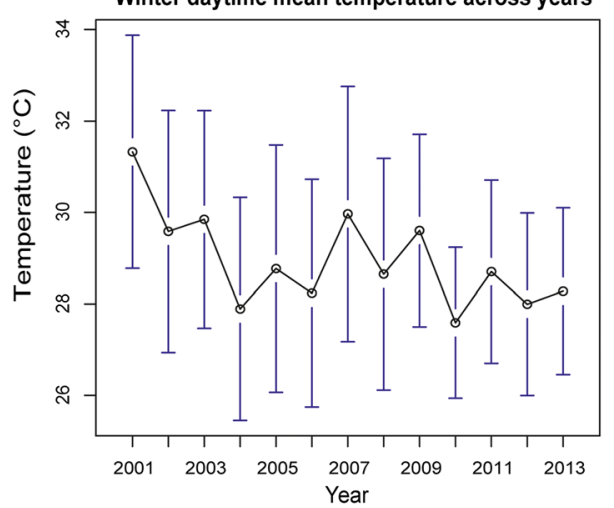

Winter peak EVI across years

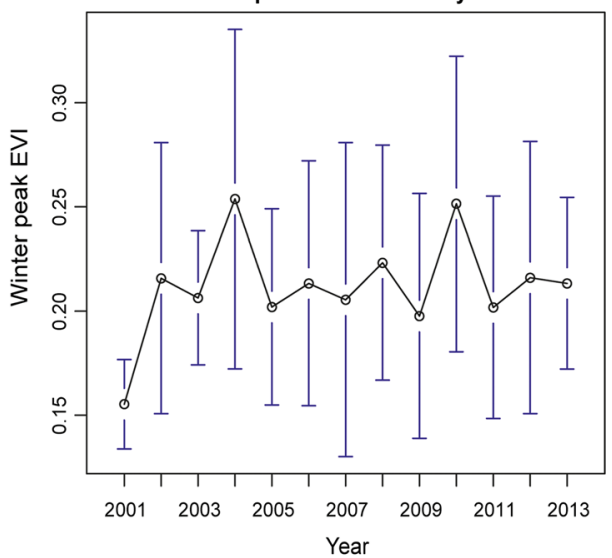

(b) Pulses

Fig. 6 Inter-annual variability in winter crop cover and climate variables for wheat (a) and pulses (b). Winter EVI for wheat and pulse fields were derived from MODIS $(250 \mathrm{~m})$, winter mean temperature and monsoon total precipitation were calculated from MODIS $(1 \mathrm{~km})$ and TRMM $(\sim 28 \mathrm{~km})$ respectively. The regression models have sample size of 502 and 64 for wheat and pulses, respectively 
crop cover, especially for wheat (Fig. 5b, c, SI Fig. 4). Compared to the 13-year mean, greater monsoon precipitation was recorded for the years 2004, 2006, and 2012 (Fig. 6). Yet, we observed higher winter crop EVI only in 2004 and 2012 (Fig. 6a, b), most likely due to lower than average temperature. The winter season of 2010 experienced one of the highest wheat EVI values in the last decade despite comparatively less monsoon rainfall (Fig. 6). Since the winter of 2010 also witnessed the lowest mean temperature in the last 13 years, the effect of a dry monsoon on winter crop was likely positively offset by the effects of a colder winter (Fig. 6). These findings corroborate other studies where wheat productivity was found to be limited by high temperatures (Kalra et al. 2008; Lobell et al. 2011, 2012; Koehler et al. 2013). In addition, our findings shed light on limiting factors for pulse productivity indicating that almost all farmers who plant winter crops in this region are vulnerable to the current and projected climate changes.

Winter wheat in India is favored in cool, moist weather during the major portion of the growing period followed by dry, warm weather during the grain-filling period. Poor drainage, rain just after sowing and overall damp climate are not suited for wheat growth as the crop is sensitive to water logging (Department of Agriculture \& Cooperation 2014a). However, wheat requires a moderate amount of water, especially during the growing stage, and soil moisture alone is not enough to get high wheat yields in this region due to sandy and loamy soils (personal observation). Besides, higher winter temperatures during the booting stage would limit soil moisture availability even when a late wet season end date and a longer wet season could potentially increase soil moisture during winter season, thus affecting the maximum attainable biomass (SI Table 4). Access to irrigation can play an important role in increasing wheat productivity. However, all four districts, except Balaghat, have irrigation in less than $30 \%$ of agricultural lands. A late and dry monsoon can thus negatively affect winter wheat productivity by limiting the water available through surface irrigation, especially in our study region where groundwater irrigation is minimal (Fig. 3b).

Pulses, on the other hand, can thrive on less soil moisture and do not need considerable amounts of irrigation in the absence of winter precipitation. Pulses can be grown on residual moisture in rainfed rice fallow lands, making it a suitable rabi crop for smallholder farmers without access to irrigation. Most of the pulse varieties (chickpea, pigeon pea, lentil, moong) in our study region have a higher optimal temperature range for germination $\left(28-35^{\circ} \mathrm{C}\right)$ compared to that for wheat $(20$ $25^{\circ} \mathrm{C}$ ) (Department of Agriculture \& Cooperation 2014a, b). Moreover, hot and humid climate is preferred during the vegetative stage for all these pulse varieties. This might explain why our finescale pulse model shows a weaker influence of temperature (Fig. 5c), although negative and more important compared to precipitation variables, on EVI when compared to the fine-scale wheat model (Fig. 5b).

The relatively stronger importance of winter daytime mean temperature compared to the precipitation parameters for irrigated wheat and un-irrigated pulses alike requires more research to understand possible adaptation strategies for rabi crops in this region. Some possible strategies shown to be important in previous studies include switching to other currently available crops that may be less sensitive to heat, shifting planting date to reduce negative heat impacts, or developing and promoting new heat-tolerant or early maturing crop varieties (Kalra et al. 2008, Ortiz et al. 2008; Gourdji et al. 2013; Mondal et al. 2013). Providing weather information to farmers may be a beneficial strategy since previous studies have shown that smallholder farmers in India change their planting behavior based on perceptions of climate (Giné et al. 2009; Wood et al. 2014); hence access to fine-scale temperature forecasts might help the farmers to decide on alternate crop types/varieties that are less susceptible to heat stress. These findings and recommendations are not only relevant in the context of India, but are also applicable to other countries in Asia with predominantly smallholder farmers and similar climate change adaptation challenges, such as Bangladesh and China. 
Acknowledgments This study was supported by NASA LCLUC grant\# 522363. We thank Harini Nagendra, Michael Bell, Benjamin Clark, and D. S. Pai for data and technical support. We also thank Pietro Ceccato, and the DeFries lab group for constructive comments on this work. The manuscript was greatly improved by constructive suggestions from three anonymous reviewers.

\section{References}

Akaike H (1974) A new look at the statistical model identification. IEEE Trans Autom Control AC-19:716-723

Benedetti R, Rossini P (1993) On the Use of NDVI profiles as a tool for agricultural statistics: the case study of wheat yield estimate and forecast in Emilia remote. Sens Environ 45:311-326

Chambers R, Pacey A, Thrupp LA (1989) Farmer first: farmer innovation and agricultural research. IT Publications, London

Chaturvedi RK, Joshi J, Jayaraman M, Bala G, Ravindranath NH (2012) Multi-model climate change projections for India under representative concentration pathways. Curr Sci 103:791-802

Chen C, Baethgen WE, Robertson A (2013) Contributions of individual variation in temperature, solar radiation and precipitation to crop yield in the North China Plain, 1961-2003. Clim Chang 116:767-788

Department of Agriculture \& Cooperation, Ministry of Agriculture, Government of India (2014a) Last accessed on June 20, 2014. Available at http://farmer.gov.in/imagedefault/pestanddiseasescrops/wheat.pdf

Department of Agriculture \& Cooperation, Ministry of Agriculture, Government of India (2014b) Last accessed on June 20, 2014. Available at http://farmer.gov.in/imagedefault/pestanddiseasescrops/pulses.pdf

Freebairn DK (1973) Income disparities in the agricultural sector: regional and institutional stresses. In: Poleman TT, Freebairn DK (eds) Food population and employment: the impact of the green revolution. Praeger, New York, pp 97-119

Frolking S, Yeluripati JB, Douglas E (2006) New district-level maps of rice cropping in India: a foundation for scientific input into policy assessment. Field Crop Res 98:164-177

Gadgil S, Kumar KR (2006) The Asian monsoon - agriculture and economy. In: Wang B (ed) The Asian monsoon. Praxis and Springer, Berlin, pp 651-683

Gajbhiye KS, Mandal C (2000) Agro-ecological zones, their soil resource and cropping systems. National bureau of soil survey and land Use. Planning, Nagpur

Galford GL, Mustard JF, Melillo J, Gendrin A, Cerri CC, Cerri CEP (2008) Wavelet analysis of MODIS time series to detect expansion and intensification of row-crop agriculture in Brazil. Remote Sens Environ 112: $576-587$

Giné X, Townsend RM, Vickery J (2009) Forecasting when it Matters: Evidence from Semi-Arid India. Mimeo World Bank

Gourdji SM, Sibley AM, Lobell DB (2013) Global crop exposure to critical high temperatures in the reproductive period: historical trends and future projections. Environ Res Lett 8:024041

Government of India (2013) Census of India 2011. Last accessed on March 25, 2014. Available at http:// censusindia.gov.in/

Huete A, Didan K, Miura T, Rodrigueza EP, Gaoa X, Ferreira LG (2002) Overview of the radiometric and biophysical performance of the MODIS vegetation indices. Remote Sens Environ 83:195-213

Indiastat (2013) District-wise irrigated area under crops. Last accessed on March 25, 2014. Available at http:// www.indiastat.com

IRI/LDEO Climate Data Library (2013) Last accessed on March 25, 2014. Available at http://iridl.ldeo.columbia. edu

Jain M, Mondal P, DeFries RS, Small C, Galford GL (2013) Mapping cropping intensity of smallholder farms: a comparison of methods using multiple sensors. Remote Sens Environ 134:210-223

Kalra N, Chakraborty D, Sharma A, Rai HK, Jolly M, Chander S, Kumar PR, Bhadraray S, Barman D, Mittal RB, Lal M, Sehgal M (2008) Effect of increasing temperature on yield of some winter crops in northwest India. Curr Sci 94:82-88

Koehler A-K, Challinor AJ, Hawkins E, Asseng S (2013) Influences of increasing temperature on Indian wheat: quantifying limits to predictability. Environ Res Lett 8:034016

Kumar KK, Kumar RK, Ashrit RG, Deshpande NR, Hansen JW (2004) Climate impacts on Indian agriculture. Int J Climatol 24:1375-1393

Kumar KR, Sahai AK, Kumar KK, Patwardhan SK, Mishra PK, Revadekar JV, Kamala K, Pant GB (2006) High-resolution climate change scenarios for India for the 21st century. Curr Sci 90:334-345

Liu MW, Ozdogan M, Zhu X (2014) Crop type classification by simultaneous Use of satellite images of different resolutions. IEEE Trans Geosci Remote Sens 52:3637-3649 
Lobell DB, Burke MB, Tebaldi C, Mastrandrea MD, Falcon WP, Naylor RL (2008) Prioritizing climate change adaptation needs for food security in 2030. Science 319:607-610

Lobell DB, Schlenker W, Costa-Roberts J (2011) Climate trends and global crop production since 1980. Science 333:616-620

Lobell DB, Sibley A, Ortiz-Monasterio JI (2012) Extreme heat effects on wheat senescence in India. Nat Clim Chang 2:186-189

Mearns LO, Rosenzweig C, Goldberg R (1996) The effect of changes in daily and interannual climatic variability on Ceres-wheat: a sensitivity study. Clim Chang 32:257-292

Mendelsohn R (2008) The impact of climate change on agriculture in developing countries. J Nat Resour Policy Res 1:5-19

Ministry of Agriculture (2010) Crop calendar of major crops. Government of India

Mondal S, Singh RP, Crossa J, Huerta-Espino J, Sharma I, Chatrath R, Singh GP, Sohu VS, Mavi GS, Sukuru VSP, Kalappanavar IK, Mishra VK, Hussain M, Gautam NR, Uddin J, Barma NCD, Hakim A, Joshi AK (2013) Earliness in wheat: a key to adaptation under terminal and continual high temperature stress in south Asia. Field Crop Res 151:19-26

Morton JF (2007) The impact of climate change on smallholder and subsistence agriculture. Proc Natl Acad Sci U S A 104:19680-19685

Mueller ND, Gerber JS, Johnston M, Ray DK, Ramankutty N, Foley JA (2012) Closing yield gaps through nutrient and water management. Nature 490:254-257

Ortiz R, Sayre KD, Govaerts B, Gupta R, Subbarao GV, Ban T, Hodson D, Dixon JM, Iván Ortiz-Monasterio J, Reynolds M (2008) Climate change: Can wheat beat the heat? Agric Ecosyst Environ 126:46-58

Pal I, Al-Tabbaa A (2010) Long-term changes and variability of monthly extreme temperatures in India. Theor Appl Climatol 100:45-56

Pal I, Al-Tabbaa A (2011) Assessing seasonal precipitation trends in India using parametric and non-parametric statistical techniques. Theor Appl Climatol 103:1-11

Peng S, Ingram KT, Neue HU, Ziska LH (1995) Climate change and rice. International Rice Research Institute (IRRI) and Springer, Manila, Philippines and Berlin, Germany

Prasad AK, Singh RP, Tare V, Kafatos M (2007) Use of vegetation index and meteorological parameters for the prediction of crop yield in India. Int J Remote Sens 28:5207-5235

Ray DK, Ramankutty N, Mueller ND, West PC, Foley JA (2012) Recent patterns of crop yield growth and stagnation. Nat Commun 3:1293

R Development Core Team (2013) R: A language and environment for statistical computing. R Foundation for Statistical Computing, Vienna, Austria. Last accessed on March 25, 2014. Available at http://www. R-project.org

Sacks WJ, Deryng D, Foley JA, Ramankutty N (2010) Crop planting dates: an analysis of global patterns. Glob Ecol Biogeogr 19:607-620

Sakamoto T, Cao PV, Nguyen NV, Kotera A, Yokoza M (2009) Agro-ecological interpretation of rice cropping systems in flood-prone areas using MODIS imagery. Photogramm Eng Remote Sens 75:413-424

Sakamoto T, Van Nguyen N, Ohno H, Ishitsuka N, Yokozawa M (2006) Spatio-temporal distribution of rice phenology and cropping systems in the Mekong Delta with special reference to the seasonal water flow of the Mekong and Bassac rivers. Remote Sens Environ 100:1-16

Sanghi A, Mendelsohn R (2008) The impacts of global warming on farmers in Brazil and India. Glob Environ Chang 18:655-665

Singh SK (2014) India Grain and Feed Annual. Global Agricultural Information Network, USDA Foreign Agricultural Service. Last accessed on March 25, 2014. Available at http://gain.fas.usda. gov/Recent\%20GAIN\%20Publications/Grain\%20and\%20Feed\%20Annual_New\%20Delhi_India_214-2014.pdf

Singh RB, Kumar P, Woodhead T (2002) Smallholder farmers in India: Food security and agricultural policy. FAO Regional Office for Asia and the Pacific, Bangkok

Tao F, Yokozawa M, Zhang Z, Hayashi Y, Ishigooka Y (2008) Land surface phenology dynamics and climate variations in the North East China Transect (NECT), 1982-2000. Int J Remote Sens 29: 5461-5478

UKAID Department for International Development (2014) PACS in Madhya Pradesh. Last accessed on March 25, 2014. Available at http://www.pacsindia.org/PACS-in-Madhya-Pradesh

Waha K, van Bussel LGJ, Müller C, Bondeau A (2012) Climate-driven simulation of global crop sowing dates. Glob Ecol Biogeogr 21:247-259

Wardlow BD, Egbert SL (2008) Large-area crop mapping using time-series MODIS 250 m NDVI data: An assessment for the U.S. Central Great Plains. Remote Sens Environ 112:1096-1116

Wheeler TR, Craufurd PQ, Ellis RH, Porter JR, Vara Prasad PV (2000) Temperature variability and the yield of annual crops. Agric Ecosyst Environ 82:159-167 
Wood SA, Jina AS, Jain M, Kristjanson P, DeFries RS (2014) Smallholder farmer cropping decisions related to climate variability across multiple regions. Global Environmental Change. http://dx.doi.org/10.1016/j. gloenvcha.2013.12.011

Xiao J, Moody A (2004) Trends in vegetation activity and their climatic correlates: China 1982 to 1998. Int J Remote Sens 25:5669-5689 